\title{
Tritrophic Interaction Between Leguminous Crops, Aphid Species and Foraging Behavior of Lady Beetles. \\ Abd El-Kareim, A. I. ${ }^{1}$ M. E. El-Naggar ${ }^{2}$ and Salma Kh. R. Mohammad ${ }^{2}$ \\ ${ }^{1}$ Economic Entomology Dept., Fac. of Agric., Mansoura Univ., Egypt. \\ ${ }^{2}$ Agric. Res. Center (ARC), Ministry of Agriculture, Egypt.
}

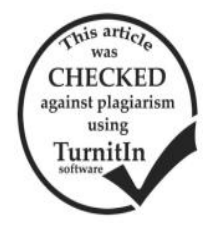

\begin{abstract}
Foraging behavior of some coccinellid predators (coccinella. Undecinpunctata L,, Coccinella septempunctata $\mathrm{L}$. and Cydoina vicina isis L.) in response to different host plants (cowpea, white bean and broad bean) and prey species (Aphis gossypii (Glover.), Myzus persicae (Sultzer.) and Aphis fabae (Scop.) ) were evaluated under laboratory conditions. The lady beetles exhibited different searching rate and matual interferace values in response to differant host plant and prey species. However, the searching rate of $C$. undecimpunctata adults was higher on $A$. gossypii than on M. persicae and $A$. fabae especially those reread on cowpea plants. While, C. septumpunctata showed the higher searching rate on M. persicae than A. fabae and A. gossypii ,especially on white bean .On contrary, the highest searching rate of the black lady beetles was recorded on $A$. fabae and $M$. persicae reared on white bean $(0.769,0.701)$ or broad bean $(0.746,0.708)$ in comparison with A. gossypii. The eleven spotted lady beetles recorded relatively higher mutual interference values in comparison with those of seven- spotted or black lady beetle adults, especially on cowpea plants. The present study revealed that the highest searching rate with relatively low mutual interference value for C. undecimpunctata $(0.763,1.881)$, C. septumpunctata $(0.781,1.626)$ and C. vicina isis $(0.769,1.684)$ were recorded on ( A. gossypii reared on cowpea), (M. persicae reared on white bean) and (A. fabae reared on white bean ), respectively.
\end{abstract}

\section{INTRODUCTION}

Legume crops are widely cultivated crops in many countries as well as in Egypt because the legume crops contain high protein that is characterized as a complete protein compared with those of other vegetables which reaches $20.25 \%$ in most dry legumes (Nosser, 1996). Legumes are sometimes called "poor people's meat" because they're an inexpensive source of quality plant protein. These crops are attacked by several insect pests throughout their different stages of their growth. Some of these insects (piercing-sucking insect pests including aphids) are very injurious and cause serious damage to the yield in both quantity and quality (Ward et al., 2002 ).

At the beginning of the twenty-first century, the need for appropriateness and effective biological control are greater than ever, especially on vegetable crops: insect pest resistance continues to be a problem, pesticides are being withdrawn on environmental grounds without suitable replacements. The use of biological control for the management of insect pests has been successfully applied against a range of openfield and greenhouse pests. Augmentative biological control and conservation have been developed with indigenous natural enemies (Bale et al, 2008).

The foraging behavior (the searching rate and interference value) of the coccinellid predators may be affected by many factors including their the prey and host plant species (Abd El-Kareim 2002, Marouf, 2007, Sarmento et al. 2007 and Al-Deghairi et al, 2014), prey density (Matter et al. 2011), foraging cues (Hodek \& Honek 1996, Pasteels 2007), (Santos-Cividanes et al. 2011). According to Snyder \& Clevenger (2004), lady bird beetles approved to be agood biological control agents against aphids. So, the present study aims to evaluate the foraging behavior ( searching rate and matual interference ) of some coccinellid species in response to host plant and aphid species.

\section{MATERIALS AND METHODS}

The present experiment aims to compare between the foraging behavior (searching rate, and mutual interference) of some predator species (Coccinella undecimpunctata L., Coccinella septempunctata $L$. and Cydonia vicina Isis L.) in response to different prey aphid species reared on various host plants (cowpea, white bean and bean).

Insect and plant sources:

Host plants: Cowpea (Vigna unguiculata L.), white bean, (Phaseolus vulgaris L.) and broad bean (vichia faba L.) were gowning in $15 \mathrm{~cm}$ diameter plastic pots under laboratory conditions.

Aphid species: the green peach aphid, Myzus persicae Sultzer, the melon aphid, Aphis gossypii Glover, and the black broad bean, Aphis fabae. Scop. were collected from vegetable fields (broad bean, white bean and cowpea). These insects were used to introduced into cages containing host plant seedlings in a pot filled with soil to establish colonies on each host plant species in the laboratory.

The tested insect predators (C. undecimpunctata, C. septempunctata. and Cyd. vicina Isis) were collected from vegetable fields (broad bean, white bean and cowpea), by using an aspirator, and kept in the laboratory for bioassay. Collected beetle females were starved for 24 hours before bioassay.

The searching rate and mutual interference values of the coccinellid predators in response to each aphid species and host plants were compared: Four densities, namely, 1, 2, 3, 4 and 5 individuals of each species, were examined by confining 50 aphid individuals (mixture of 2 nd and 3rd nymphal instars) of A. faba, A. gossypii and M. persica on each host plant seedling (cowpea, white bean and bean ) with each density of predator in a glass containers $(6 \times 30 \mathrm{~cm})$. The upper rim of the container was covered with mesh screen and fixed with a rubber band. The predators were left in the container for $24 \mathrm{hrs}$. with their prey, predated 
preys were counted and recorded. Each predator density was replicated five times. The experiments were conducted under laboratory conditions $(26 \pm 2.5 \circ \mathrm{C}$ and $68 \pm 4.5 \mathrm{RH} \%$ ).

The searching rate (at) was calculated according to Varley et al. (1978) as followed:

$$
a_{t}=(1 / p) \text { loge }(N / S)
$$

(Where, $\mathrm{P}=$ number of predators, $\mathrm{N}=$ the initial number of prey and $\mathrm{S}=$ number of preys not predated)

The relationships between the searching rate $\left(a_{t}\right)$ and predator density $(\log p)$ are indicated by the slope of the equation:

\section{$\log a_{\mathbf{t}}=\log Q-\mathbf{m} \log p$}

(Where Q; is the quest value (the search rate when the predator density is one ; $\mathrm{m}$; is the mutual interference value)

\section{RESULTS}

1. Tri.trophic interaction between leguminous plants, aphid and searching behavior of coccinellid predators.

Searching rate and mutual interference values of each predators $(C$. undecimpunctata, $C$. septempunctata and $C y d$. Vicina isis) were estimated in response to both host plants (cowpea, white bean and broad bean)and aphid (A. gossypii, A. fabae and M. persicae) species.

\section{Eleven-spotted ladybird, $C$. undecimpunctata.}

The searching rate $\left(a_{t}\right)$ and mutual interference values $(m)$ for the predator were estimated in response to different aphid species reared on various host plants (cowpea, white bean and broad bean).

In response to $A$. gossypii.

The searching rate of the predator $C$. undecimpunctata at different adult densities is illustrated in Figure (1). The predator showing relatively higher searching rate $(0.763)$ on $A$. gossypii -reared on cowpea in comparison with those reared on white bean $(0.721)$ or broad bean $(0.571)$. On contrary, the highest mutual interference value (1.881) was recorded on cowpea followed by white bean (1.611) and broad bean (1.683). Therefore, by increasing predator density, searching rate per adult was relatively decreased on cowpea (Figure 1 )

In response to $M$. persicae.

As shown in Figure ( 1), the predator showing relatively higher searching rate $(0.654)$ on the preyreared on cowpea followed by 0.574 and 0.515 on broad bean and white bean, respectively. On contrary, mutual interference value was the reverse of that of searching rate, where, the lowest value was (1.844) recorded on white bean followed by (1.964) and (2.177) on broad bean and cowpea, respectively.

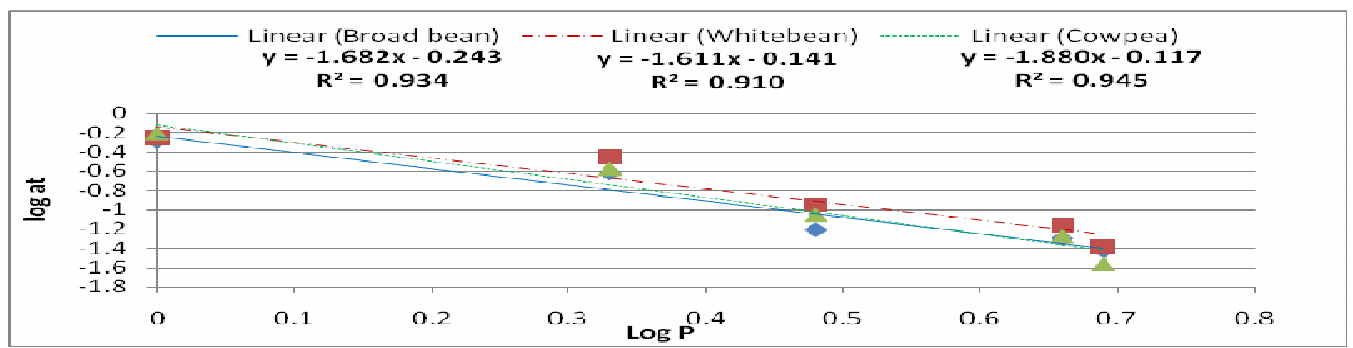

A. gossypii

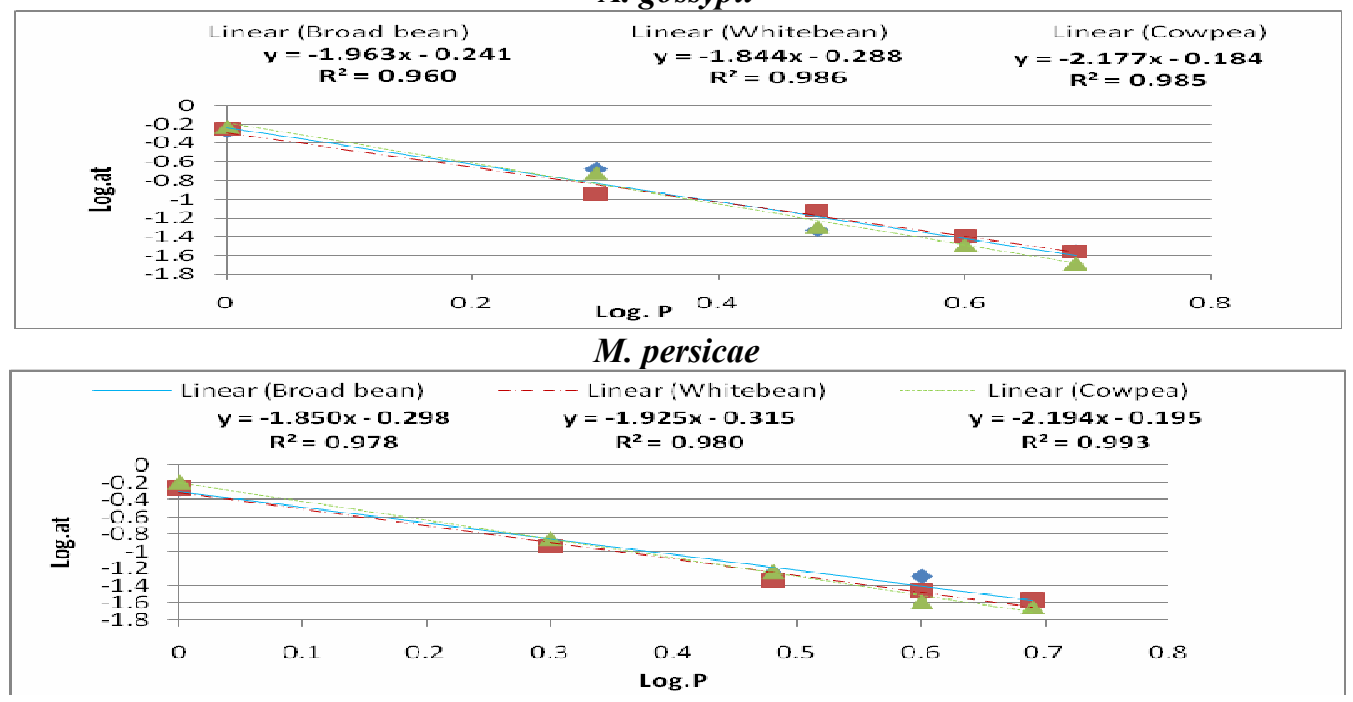

A. fabae

Figure 1. The relation between predator density $(\log p)$ and searching rate $\left(\log a_{t}\right)$ of Coccinella undecimpunctata response to Aphis gossypii (Glover.), Myzus persicae (Sultzer.) and Aphis fabae( Scop.) reared on cowpea, white bean and broad beean.

In response to $A$. fabae.

Data illustrated in Figure(1) and presented in Table (1), cleared that foraging behavior (the searching rate and mutual interference value) of $C$. undecimpunctata adults was similar as mentioned above. The predator showing relatively higher searching 
rate $(0.0 .638)$ on the prey-reared on cowpea with relatively higher mutual interference (2.195). While, the predator exhibited the lowest mutual interference value (1.850) on broad bean with low searching rate (0.504). Searching rate and mutual interference value of the ladybird on $A$. fabae reared on white bean were inbetweens, represented by, 0.484 and 1.925 , respectively.

In general, it could be concluded that searching rate of $C$. undecimpunctata adults was higher on $A$. gossypii than on $M$. persicae and $A$. fabae, especially on cowpea plaants.

Seven-spotted ladybird, $C$. septumpunctata $\mathrm{L}$.

The searching rate $\left(\mathrm{a}_{\mathrm{t}}\right)$ and mutual interference values for $C$. septumpunctata were estimated in response to different aphid species reared on the previously mentioned host plants.
In response $A$. gossypii.

The searching rate of the predator $C$. septumpunctata at different adult densities is illustrated in Figure (2). The predator showing relatively higher searching rate $(0.553)$ on the prey-reared on white bean with low mutual interference value (1.764), in comparison with those reared on broad bean $\left(\mathrm{a}_{\mathrm{t}}=0.543\right.$ $\& \mathrm{~m}=1.836)$ or cowpea $\left(\mathrm{a}_{\mathrm{t}}=0.445 \& \mathrm{~m}=1.927\right)$.

In response to $M$. persicae.

The searching rate of the predator $C$. septumpunctata at different adult densities is illustrated in Figure (2). The predator showing relatively higher searching rate $(0.781)$ on the prey-reared on white bean in comparison with those reared on broad been $(0.741)$ or cowpea (0.675).
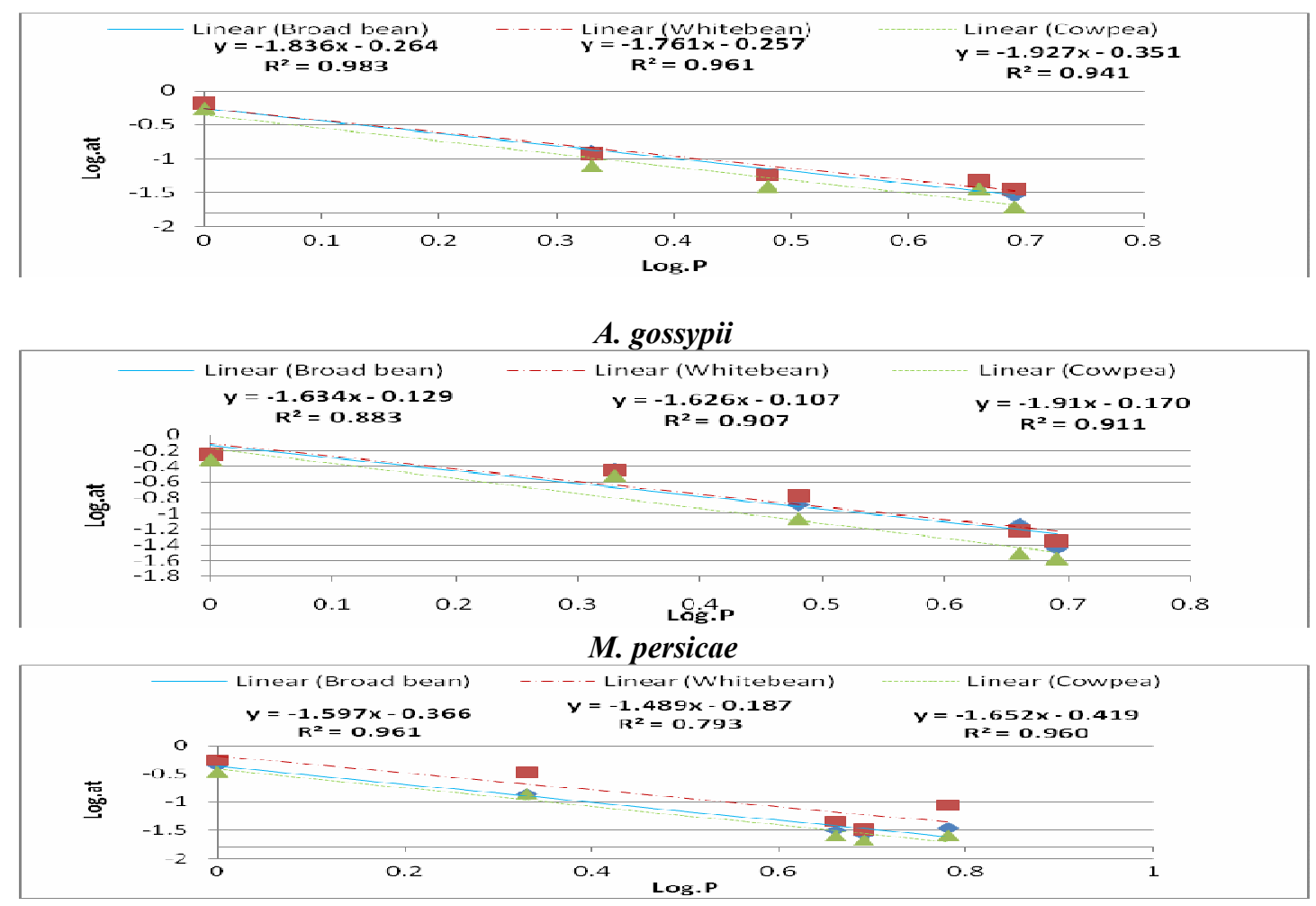

A. fabae

Figure 2. The relation between predator density $(\log p)$ and searching rate $\left(\log a_{t}\right)$ of Coccinella septumpunctata response to Aphis gossypii (Glover.), Myzus persicae (Sultzer.) and Aphis fabae (Scop.) reared on cowpea, white bean and broad beean.

Mutual interference value on all tested host plants (cowpea, broad bean and white bean) was 1.910 , 1.634 and 1.626 , respectively.

In response to $A$. fabae.

Foraging behavior of the predator $C$. septumpunctata at different adult densities is illustrated in Figure (2). The predator showing relatively higher searching rate $(0.649)$ on the prey-reared on white bean in comparison with those reared on broad bean $(0.431)$ cowpea (0.381). Mutual interference value was 1.652 , 1.598 and 1.489 on cowpea, broad bean and white bean, respectively.

In general, it could be concluded that searching rate of $C$. septumpunctata adults was higher on $M$. persicae than on and A. fabae A. gossypii, especially on cowpea plants.
Black ladybird, Cydonia vicina isis

The searching rate $\left(a_{t}\right)$ and mutual interference values for the predator were estimated in response to different aphid species reared on cowpea, white bean and broad bean.

\section{In response to $A$. gossypii.}

The searching rate of the predator Cydonia vicina isis at different adult densities is illustrated in Figure (3). The highest searching rate of the black ladybird, was $(0.667)$ recorded on the prey-reared on broad bean in comparison with those reared on white bean $(0.659)$ and cowpea (0.627). While, the predator exhibited the lowest mutual interference value on broad bean (1.579) and the highest on cowpea (1.856) and white bean (1.622) 


\section{In response to $M$. persicae.}

The searching rate of the predator Cydonia vicina isis at different adult densities is illustrated in Figure (3). The predator showing relatively higher searching rate $(0.708)$ on the prey-reared on broad bean in comparison with those reared on white bean $(0.701)$ or cowpea (0.618). Mutual interference value on all tested host plants (whitebean, broad bean and cowpea) was $1.777,1.785$ and 1.882 , respectively. Therefore, by increasing predator density, searching rate per larvae was relatively decreased (Figure3 ).

\section{In response to $A$. fabae.}

The searching rate of the predator Cydonia vicina isis at different adult densities is illustrated in Figure
(3). The predator showing relatively higher searching rate $(0.769)$ on the prey-reared on white bean in comparison with those reared on broad bean $(0.746)$ or cowpea (0.579). Mutual interference value on all tested host plants (broad bean, white bean and cowpea) was $1.684,1.702$ and 1.714 , respectively. Therefore, by increasing predator density, searching rate per larvae was relatively decreased (Figure 3 ).

The obtained results revealed that searching rate of Cyd.vicina isis adults was higher on A. fabae and $M$. persicae than on $A$. gossypii, especially on broad bean and white bean plants.

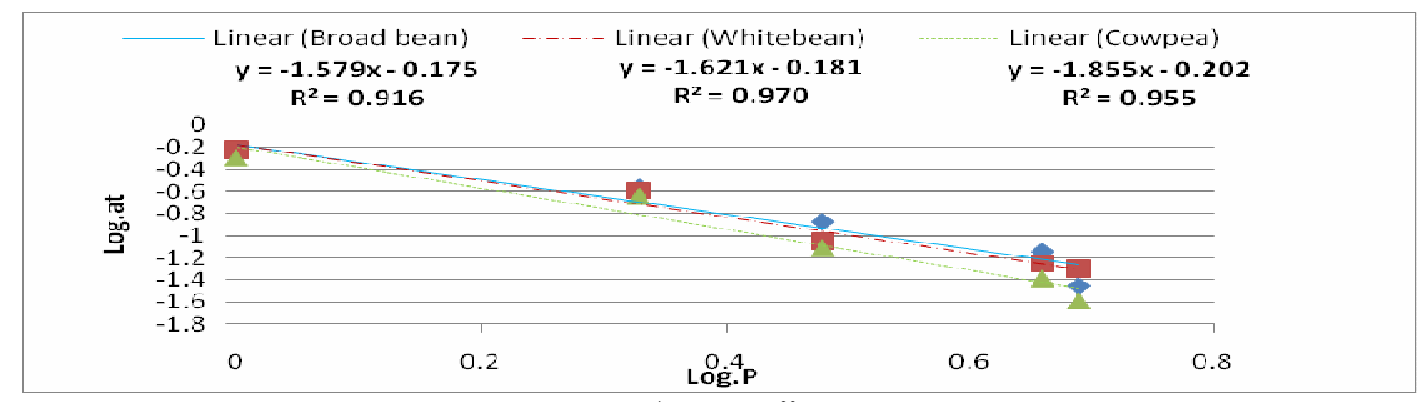

A. gossypii

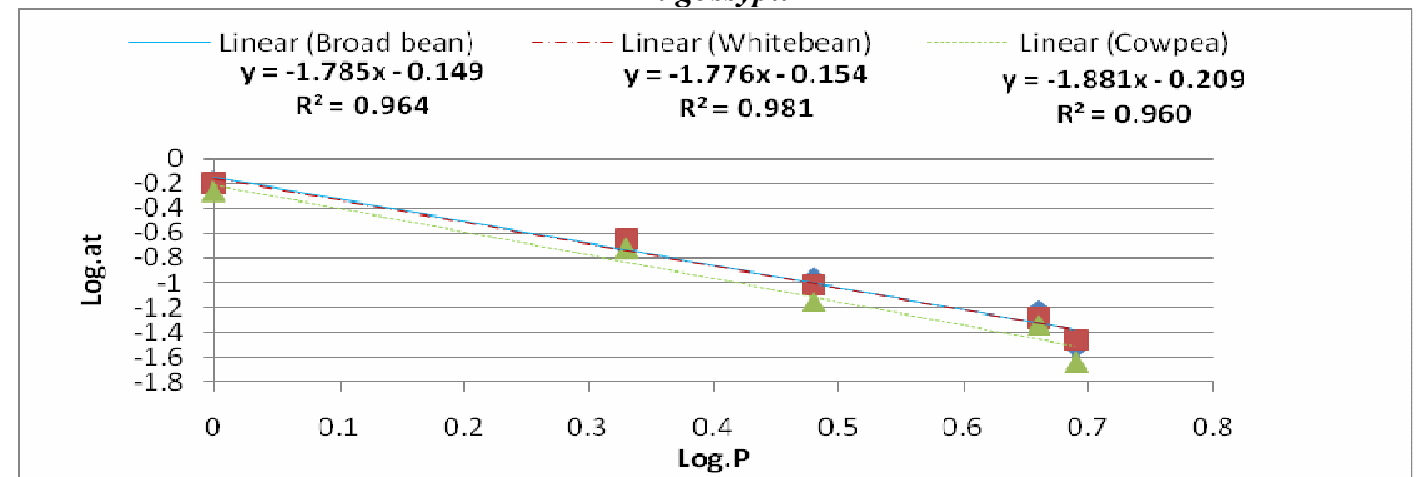

M. persicae

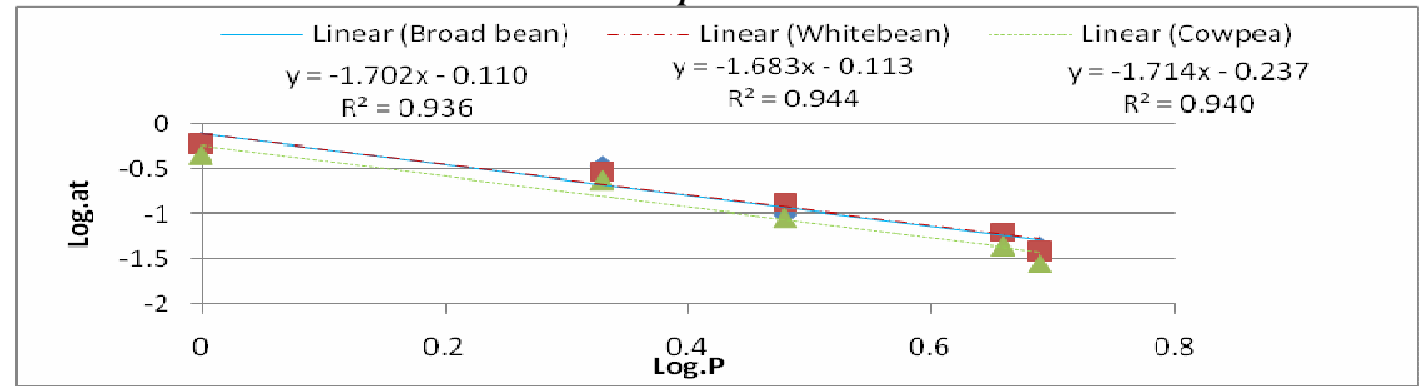

A. fabae

Figure 3. The relation between predator density $(\log p)$ and searching rate $\left(\log a_{t}\right)$ of Cydonia vicina isis L.response to Aphis gossypii (Glover.), Myzus persicae (Sultzer.) and Aphis fabae reared on cowpea, white bean and broad beean.

\section{DISCUSSION}

The present results indicated that the searching rate of tested predators was decreased as the predator density increased. Similar conclusion wasobtained by Abd El-Fattah et al. (1987), Abd El-Kareim (1998) and El-Batran (2003).
According to Abd El-Kareim (2002) the searching characteristics (searching rate and interference value) of the predators (C. bipustulatus, $E$. flavipes and $C$. undecimpunctata) were affected by the prey and host plant species. The present investigation also, revealed that the searching rate and interference value of $C$. undecimpunctata, C. septeumpunctata, and Cyd. vicina isis were affected by host plant species. $\mathrm{Wu}$ 
et al., (2010) demonstrated that the suitability of $A$. gossypii from different host plants (Cucumis sativus L., Cucurbita pepo., Cucurbita moschata, Cucumis melo L. and Lagenaria siceraria) was different for the ladybird beetle, $H$. variegate. The cocinellid Nephus reunioni showed different searching behavior to the mealybugs, Planococcus citri and P. affinis on six host plants (Copland et al., 1993). Also, the efficiency of the coccinellid predators ( $R$. cardinalis and C. bipustulatus) was affected by host plant species (Abdel-Mageed, 2005). Heidari et al. (1999) added that the type of host plant leaf trichemes have a marked influence on the level of mealybug control by C. montrouzieri.

The searching rate of the tested predators was affected according to prey spesies. However, the highest searching rate of $C$. undecimpunctata, $C$. septumpunctata and Cyd.vicina isis adults was recorded on $A$. gossypii M. persicae and A. fabae, respectively. This results coupled with those recorded by Abdelkareim (2002), Sarmento et al. (2007), Jalali (2012), AlDeghairi et al. (2014), which suggested that foraging behavior of the predators were different with respect to aphid species . Also, the coccenelid predators, R. cardinalis and C. montrouzieri exhibited different response to different host plants (Cardosa, 1990). The coccinellid Nephus reunioni showed different searching behavior to the mealybugs, Planococcus citri and $P$. affinis on six host plants (Copland et al., 1993).Heidari et al. (1999) added that the type of host plant leaf trichomes have a marked influence on the level of mealybug control by C. montrouzieri. According to Pervez and Omkar (2005) the coccinellid predators exhibited differences in handling times within and between the predatory species on both prey species (Aphis craccivora and Myzus persicae indicating that predators respond differentially to prey species.

So, it could be concluded that $C$. undecimpunctata may be more suitable as biological control agent for A. gossypii as well as C. septumpunctata and Cyd.vicinna isis for M. persciace and $A$. fabae, respectively.

Table 1. Searching rate and matual interference values of the coccinellid predators in response to different aphid species reared on various host plants.

\begin{tabular}{lcccccc}
\hline \multirow{2}{*}{ Ladybirds/ Aphids } & \multicolumn{2}{c}{ Broad bean } & \multicolumn{2}{c}{ White bean } & \multicolumn{2}{c}{ Cowpea } \\
& $\mathbf{a}_{\mathbf{t}}$ & $\mathbf{m}$ & $\mathbf{a}_{\mathbf{t}}$ & $\mathbf{M}$ & $\mathbf{a}_{\mathbf{t}}$ & $\mathbf{M}$ \\
\hline $\begin{array}{l}\text { Coccinella undecimpunctata L. } \\
\text { Aphis gossypii(Glover.) }\end{array}$ & 0.571 & 1.683 & 0.721 & 1.611 & 0.763 & 1.881 \\
$\begin{array}{l}\text { Myzus persicae(Sultzer.) } \\
\text { Aphis fabae (Scop.) }\end{array}$ & 0.574 & 1.964 & 0.515 & 1.844 & 0.654 & 20177 \\
Coccinella septumpunctata L. & 0.504 & 1.850 & 0.484 & 1.925 & 0.638 & 2.195 \\
Aphis gossypii(Glover.) & 0.543 & 1.836 & 0.553 & 1.761 & 0.445 & 1.927 \\
Myzus persicae(Sultzer.) & 0.741 & 1.634 & 0.781 & 1.626 & 0.675 & 1.910 \\
Aphis fabae(Scop.) & 0.431 & 1.598 & 0.649 & 1.489 & 0.381 & 1.652 \\
Cydonia vicina isis L. & 0.667 & 1.579 & 0.659 & 1.622 & 0.627 & 1.856 \\
Aphis gossypii(Glover.) & 0.708 & 1.785 & 0.701 & 1.777 & 0.618 & 1.882 \\
Myzus persicae(Sultzer.) & 0.746 & 1.702 & 0.769 & 1.684 & 0.579 & 1.714 \\
Aphis fabae(Scop.) & & & & &
\end{tabular}

\section{REFERENCES}

Abdel-Fattah, M.I.; El- nabawi, A. and Hendi, A. (1987). Effect of intra and inter-specific larval competition on the development of certain aphidophagous predators (Coleoptera: Coccinellidae). Bull. Soc. Ent. Egypt, 65: 73-79.

Abd El-Kareim, A.I. (1998). Searching rate and potential of some natural enemies as bio- agent against the cottonwhitefly, Bamisia tabaci, Genn (Hom: Aleyrodidae). J.App. Ent., 122: 487-492

Abd El-Kareim, A.I. (2002). The potential of some natural enemies as bio-agent against certain disaspidid species. J. Union Arab. Biol.Cairo,17(A): Zoology, 51-63.

Abdel- Mageed, Sanaa, A.M. (2005). Influence of certain natural enemies on some mealy bug populations. M. Sc. Thesis, Fac. Agric., Mans, Unvi Egypt, P.154.
Al-Deghair, M. A.; N. F. Abdel-Baky; A. H. Fouly; and N. M. Ghanim (2014). Foraging behavior of two coccinellid species ( Coleoptera: Coccinellidae ) fed on aphids. J. Agric. And Urban Entomol. 30(1):12-24.

Bale, F.B.; Lenteren. J.C.V.; Hokkanen, H.M.T. and Loomans, A.J.M. (2008). Assessing risks of releasing exotic biological control ageist of arthropod pests. Annual. Rev. Entomol. 15: 609634.

Copland, M.J.W,; Perera, H.A.S. and Heidari, M. (1993). Influence of host plant on the biocontrol of glasshouse mealybug. Bull. Oil/SROP 16(8): 44-47.

Cardosa, A. (1990). Preliminary study of coccinellids found on citrus in portugal. Boletin de Vegetal, Plagas, 16(1): 105-111.

El-Batran, L.A. (2003). Laboratory studies on searching behavior of larvae of Exochomus flavipes (Thunb) and Chrysoperla carnea (Steph) for Coccus hesperdum L. Egypt. J. Bio. P. Cont., 7(2): 103105. 
Heirdie, J.; Picket, J.A.; Pow, E.M. and ; Smiley, D.w.M.(1999). Pheromones of non- Lepidopteran insects associated with agricultural plants. $\mathrm{CAB}$. Inter. PP. 227-250.

Hodek and Honek. (1996). Ecolgy of Coccinellidae. Lin. 54: 95-141.

Jalali, M.A. and Michaud, J.P. (2012). Aphid-plant interactions affect the suitability of Myzus spp. As prey for two spot ladybird, Adalia bipunctata (Coleoptera: Coccinellidae). Eur.J. Entomol., 109: 345-352.

Marouf, A.H. (2007). Stusies on insect pests and their natural enemies assotiated with marjoram and chamomile plants. M. Sc. Thesis, Fac. Agric. Mans. Unvi. Mans. Egypt, P. 150.

Matter, M.M.M.; Mahasen, E.N.A.; Ferag, E.N.A. and Gasraha, M.A. (2011). Impact of temperature and prey density on the predacious capacity and behavior of Stethorus punctillum Weise. Arch. Phytopa. Plant. Protec. 44: 127-134.

Nosser, M.A. (1996). Mechanism of resistance in bean and cowpea varieties to certain sucking insects infestation. M. Sc. Thesis, Fac. Agric., Cairo Univ

Pasteels, J.M. (2007). Chemical defense, offence and alliance in ants-aphids-ladybirds relationsheps. Pop. Ecol. 49: 5-14.

Pervez, A. and Omkar. (2005). Functional responses of coccinellid predators : An illustration of a logistic approach. J. Insect. Sci.5:5.

Santos-Cividanes, T.M.; Anjos, A.C.R. Cividance, F.J. and Dias, P.C. (2011). Effects of food deprevation on the development of Coleomegilla maculate (De Geer) (Coleoptera: Coccinellidae). Neeotrop. Entomol. 40: 112-116.
Sarmento, R.A.; Pallini, A.; Venzon, M.; Francisco,o.F.S.; Rugama, A.J.M. and Oliviera, C.L. (2007). Functional response of the predator Eriops connexa (Coleoptera: Coccinellidae) to different prey types . Braz. Arch. Biol.Technol. 50(1).

Snyder, W. E., and Garrett M. C. (2004). "Negative Dietary Effects of Colorado Potato Beetle Eggs for The Larvae of Native and Introduced Ladybird Beetles". Biol. Cont. 253:(3) 31-61.

Varley, G.C.G.R,; Gradwell and Hassell, M.P. (1978). Insec Population. Ecol. Oxford: Blackwell.

Vet, L.E.M. and Dick, M. (1992). Ecology of infochemical use by natural enemies in tritrophic context. Annu. Rev. Entomol. 37: 141-172.

Ward, A.S.W.; Denholm, I. and Nammara, N.M.C. (2002). Foliar insect pest management on cowpea ( Vigna ungiculata (L.) Walpars) in simulated varietal mixures. Field- Crops-Research. 79(1): 53-65.

Wu, X. H. ; Zhuo, X. R. and pang ,B. P. (2010). Influence of five host plants of Aphis gossypii Glover on some population parameters of Hippodamia variegate (Goeze). J. Pest Science .83 (2): 77-83.

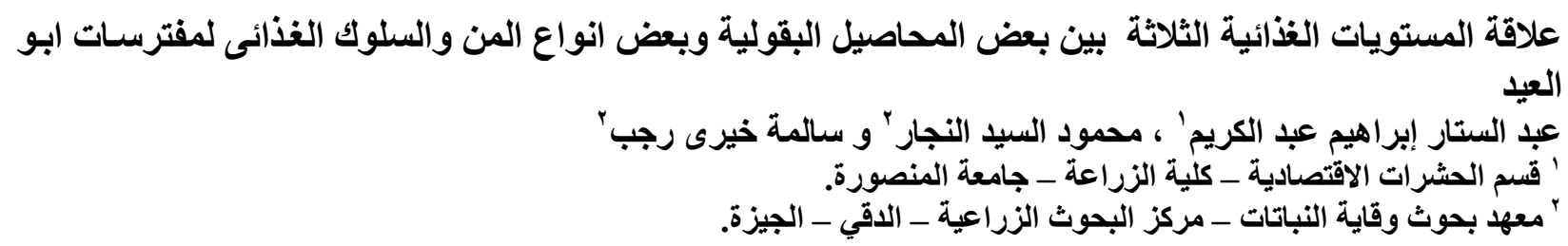

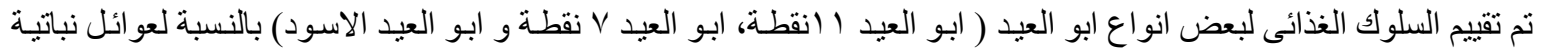

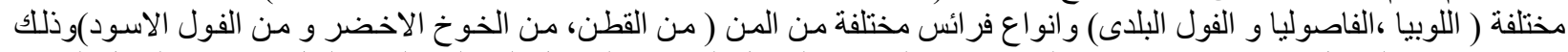

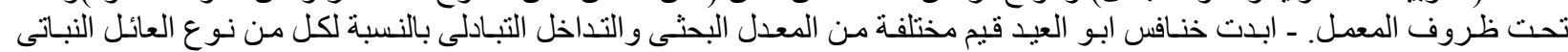

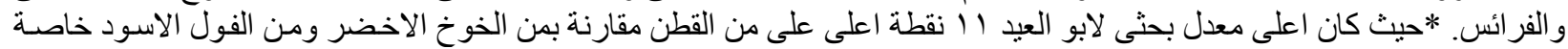

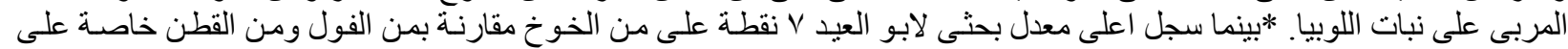

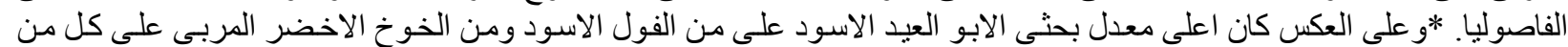

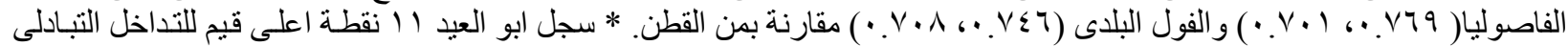

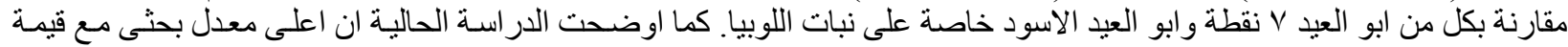

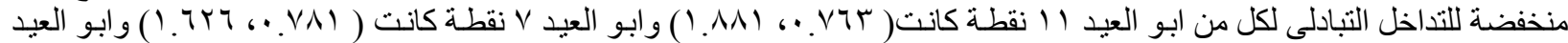

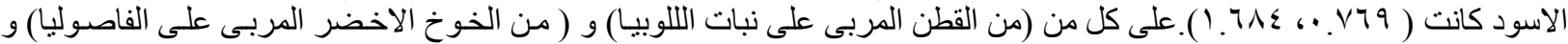
( من الفول الاسود على الفاصوليا) نسبيا. 